\title{
Erratum to: A Combination of Melatonin and Alpha Lipoic Acid has Greater Cardioprotective Effect than Either of them Singly Against Cadmium-Induced Oxidative Damage
}

\section{Raktim Mukherjee $\cdot$ Sudeep Banerjee $\cdot$}

Niraj Joshi · Prem Kumar Singh · Darshee Baxi •

A. V. Ramachandran

Published online: 16 November 2010

(C) Springer Science+Business Media, LLC 2010

Erratum to: Cardiovase Toxicol

DOI 10.1007/s12012-010-9092-9

In Fig. 3, in the original publication, the unit for GPX in the figure should be ' $\mu$ moles of GSH consumed/min/mg protein'. The corrected figure appears below.

The online version of the original article can be found under doi: 10.1007/s12012-010-9092-9.

R. Mukherjee - S. Banerjee - N. Joshi · P. K. Singh - D. Baxi ·

A. V. Ramachandran $(\bowtie)$

Division of Cardiotoxicity, Department of Zoology,

Faculty of Science, The Maharaja Sayajirao University

of Baroda, Vadodara 390 002, Gujarat, India

e-mail: avrcn2008@yahoo.co.in

Present Address:

R. Mukherjee

Shree PM Patel College of PG Studies and Research in Science,

Affiliated to SP University, Anand, Gujarat, India 

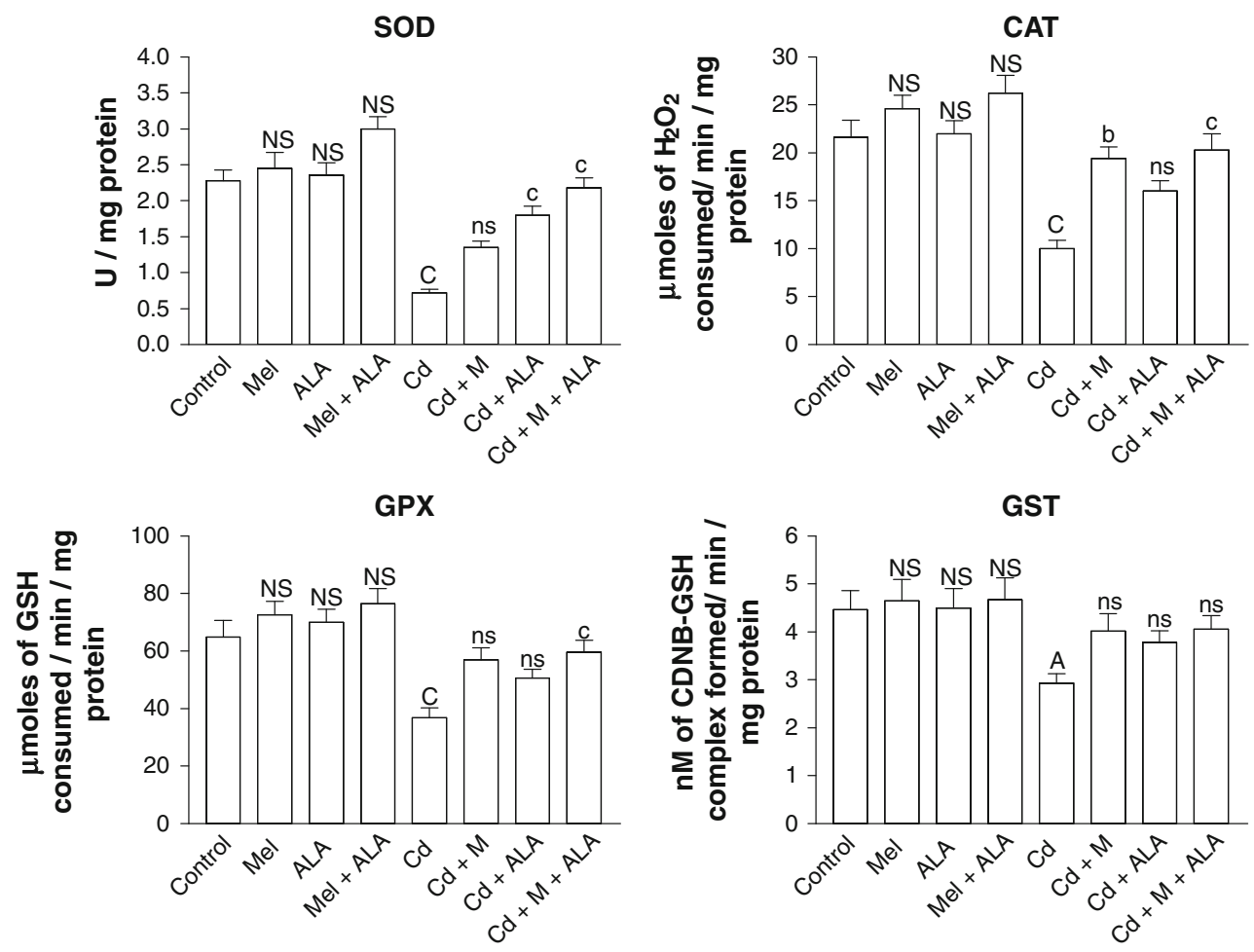

Fig. 3 Effect of simultaneous administration of melatonin + ALA combination on the status of enzymatic antioxidants in the heart of cadmium-treated animal. Values are expressed as mean \pm SEM for $n=6$, where, $\mathrm{C}(P<0.001)$ and $N S$ non-significant when control

versus Mel, ALA, Mel + ALA, Cd and, a $(P<0.05), \mathrm{b}(P<0.01), \mathrm{C}$ $(P<0.001)$ and $n s$ non-significant when $\mathrm{Cd}$ versus $\mathrm{Cd}+\mathrm{M}$, $\mathrm{Cd}+\mathrm{ALA}, \mathrm{Cd}+\mathrm{M}+\mathrm{ALA}$ 